\title{
A Case of Parathyroidectomy of Supernumerary Parathyroid Glands Using Intraoperative IPTH Monitoring
}

\author{
Dong Yeol Han ${ }^{1}$, Jin Kuk Kim ${ }^{2}$, Yong Wha Lee ${ }^{3}$ and Seung Won Lee ${ }^{1}$ \\ ${ }^{1}$ Department of Otorhinolaryngology-Head and Neck Surgery, ${ }^{2}$ Internal Medicine, ${ }^{3}$ Laboratory Medicine, \\ Soonchunhyang University College of Medicine, Bucheon, Korea \\ 술 중 부갑상선 호르몬 측정을 이용해 제거한 초과수 2 차성 부갑상선 기능 항진증 1 예 \\ 한동열 ${ }^{1} \cdot$ 김진국 $^{2} \cdot$ 이용화 ${ }^{3} \cdot$ 이승원 $^{1}$ \\ 순천향대학교 의과대학 이비인후-두경부외과학교실, ${ }^{1}$ 내과학교실, ${ }^{2}$ 진단검사의학과학교실 ${ }^{3}$
}

\section{Received November 25, 200 \\ Revised January 4, 2010 \\ Accepted January 11, 2010}

Address for correspondence

Seung Won Lee, MD

Department of Otorhinolaryngology-

Head and Neck Surgery,

Soonchunhyang University College

of Medicine, 1174 Jung-dong,

Wonmi-gu, Bucheon 420-767, Korea

Tel $+82-32-621-5450$

Fax $+82-32-621-5440$

E-mail1sw0922@schbc.ac.kr
The incidence of hyperparathyroidism has slowly increased recently with routine measurement of serum calcium and increasing awareness of the disease by the public. Despite the availability of expert surgeons and preoperative imaging investigations, some patients are re-operated for persistent or recurrent hyperparathyroidism. The main cause of re-operation is the presence of ectopic parathyroid gland or supernumerary parathyroid gland. Supernumerary parathyroid glands are more frequently described in the secondary hyperparathyroidism than in the primary hyperparathyroidism cases, especially in surgery for renal hyperparathytroidism. The intraoperative measurement of intact parathyroid hormone (iPTH) provides the surgeon with a quantitative test that predicts the postoperative serum calcium level and can justify early closure or further exploration for hyperfunctioning parathyroid gland. We present a case of parathyroidectomy of supernumerary parathyroid glands by monitoring intraoperative iPTH in patients with secondary hyperparathyroidism. Korean J Otorhinolaryngol-Head Neck Surg 2010;53:190-3

Key Words Parathyroid gland · Parathyroid hormone $\cdot$ Secondary hyperparathyroidism.
서 론

이차성 부갑상선 기능항진증은 대부분 만성 신부전에 의 해 발생하며, 과잉 생산된 부갑상선 호르몬으로 인해 골조 직을 비롯한 체내 조직에서 칼슘이 배출되어, 골다공증과 골 통증, 급성 신장통, 체중감소, 식욕부진 등과 같은 증상을 유 발한다. 일차성 및 이차성 부갑상선 기능항진증에 대해 외과 적 수술은 95 98\%의 완치율을 가진 효과적 치료법이다. ${ }^{1)}$ 부갑상선은 보통 좌우 2 개씩 4 개가 있는 것이 보통이나 간 혹 그 이하나 이상으로 있는 경우가 있는데, 부검상 4 개 이 하로 있는 경우가 $3 \%$, 이상으로 있는 경우가 $13 \%$ 정도로 보고되고 있다. ${ }^{2)}$ 저자들은 만성 신부전에 의한 이차성 부갑 상선 기능항진증을 가진 50세 남자 환자에서 부갑상선 전 절제술 중 초과수 부갑상선을 발견하여, 초과수 부갑상선을 제거하였다. 수술 종료 후 다시 점진적으로 부갑상선 호르몬
이 증가되어 2차 부갑상선 탐색술을 진행하여 잔존 초과수 부갑상선을 확인하고 제거한 이후 재발 소견을 보이지 않고 성공적으로 치료된 환자를 치험하였기에 문헌 고찰과 함께 보고하고자 한다.

\section{증 례}

과거력상 약 15 년 전 만성 신부전으로 진단 받은 후, 최 근 6 개월 전부터 주 3 회 혈액투석을 시행 중인 50세 남자 환자가 높은 혈중 부갑상선 호르몬 수치 및 골 통증을 주소 로 내원하였다. 전신문진상 가끔 양측 손과 발저림, 근육통 증상을 호소하였으며 전신쇠약감, 변비, 급성 신장통이나 병적골절, 급성소화기 장애 등과 같은 증상은 없었다. 신체 검사상 전경부 영역에 명확한 종괴의 소견은 없었고, 측경 부에서도 증대된 림프절은 만져지지 않았다. Tc-99m tet- 
rofosmin scan에서 우측 부갑상선 주위로 음영 증가 소견 보였으며(Fig. 1), 경부 전산화단층촬영 소견에서 양측 갑 상선 후방으로 다수의 부갑상선 결절이 관찰되었다(Fig. 2). 술 전 시행한 혈액검사에서 총 칼슘치는 $10.4 \mathrm{mg} / \mathrm{dL}$, 부 갑상선 호르몬 수치는 $2,790.0 \mathrm{pg} / \mathrm{mL}$ 로 증가되어 있었다. 환자는 만성 신부전에 의한 이차성 부갑상선 기능항진증 진단하에 2009년 8월 18일 부갑상선 전절제술을 시행하 였다. 수술은 경부 절개를 통해 양측의 부갑상선에 대한 탐 색을 계획하고, 술 중에 부갑상선 종괴 탐색 후 부갑상선 호 르몬 수치의 변화를 측정하기로 하였다. 술 중 부갑상선 호 르몬을 측정하는 방법은 여러 가지가 알려져 있고, 본원에 서는 Immunochemiluminometric assay(ICMA, E170, Roche, USA) 방법을 사용하였고, 혈액 채취 후 술 전과 비 교하여 호르몬치 변화가 $50 \%$ 이상 감소한 상태로 증식된 부갑상선을 모두 제거한 것으로 간주하였다. 탐색은 우측 상부 부갑상선, 우측 하부 부갑상선, 좌측 하부 부갑상선, 좌 측 상부 부갑상선의 순으로 진행하였으며, 부갑상선의 정 확한 확인을 위해 methylene blue $1 \%$ 용액 $(7.5 \mathrm{~g} / \mathrm{kg})$ 을 생리식염수 $400 \mathrm{cc}$ 와 혼합하여 체내 정주하였다. 각 종괴 는 동결절편검사에서 부갑상선임이 확인되었고, 각 종괴
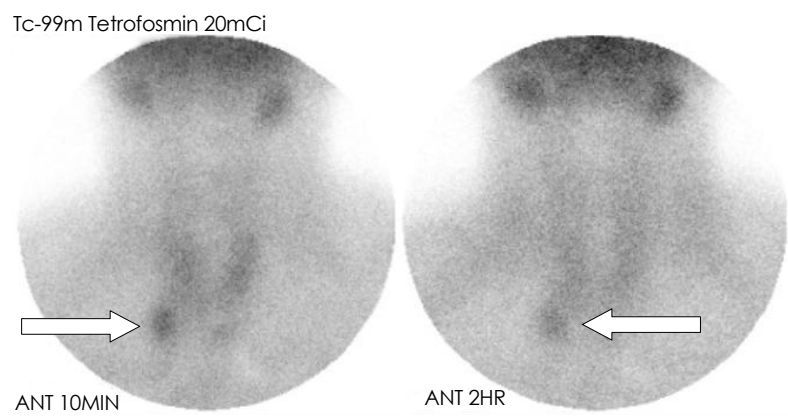

Fig. 1. Pre-operative Tc-99m tetrofosmin scan shows abnormal tetrofosmin accumulation in the lower pole of right lobe (arrow).
제거 후 10 분, 20 분, 60 분 후에 정맥혈을 채취하여 $\mathrm{iPTH}$ 의 감소 여부를 확인하였다. 그러나 10 분, 20 분, 60 분 후의 iPTH는 1,597.0 pg/mL, 1,592.0 pg/mL, 1,232.0 pg/mL 로 약간의 감소 소견을 보였으며(Fig. 3), 재차 갑상선 주 위를 중심으로 재탐색 결과 좌측 갑상선 중심 경부절 부위 에서 초과수 부갑상선을 1 개 확인하여 제거하고 수술을 종 료하였다(Fig. 4A), 술 후 1일째, 5일째, 10일째 iPTH는 각각 $932.4 \mathrm{pg} / \mathrm{mL}, 1,490.0 \mathrm{pg} / \mathrm{mL}, 2,111.8 \mathrm{pg} / \mathrm{mL}$ 로 술 전과 비교하여 큰 차이가 없었다. 1 주일 후 시행한 $\mathrm{Tc}-$ $99 \mathrm{~m}$ tetrofosmin 스캔과 SPECT-CT 촬영에서 우측 식도 뒷공간(retroesophageal space) 부위에 부갑상선 증식증 으로 의심되는 부갑상선 조직의 음영 증가 소견을 보여(Fig. $4 \mathrm{~B})$, 초과수 부갑상선의 완전 제거를 위해 2009년 9 월 2 일 재수술을 시행하였다. 1차 수술과 동일하게 methylene blue를 이용하여 정확한 부갑상선 조직을 확인하려 했으며, 부갑상선 조직의 제거 10 분, 20 분, 60 분 후의 술 중 $\mathrm{iPTH}$ 를 측정하기로 계획하였다. 우측 식도뒷공간(retroesophageal space) 부위에서 초과수 부갑상선을 확인 후 제거하 였으며 양측 흉선 조직을 같이 제거하였다(Fig. 5). 부갑상선

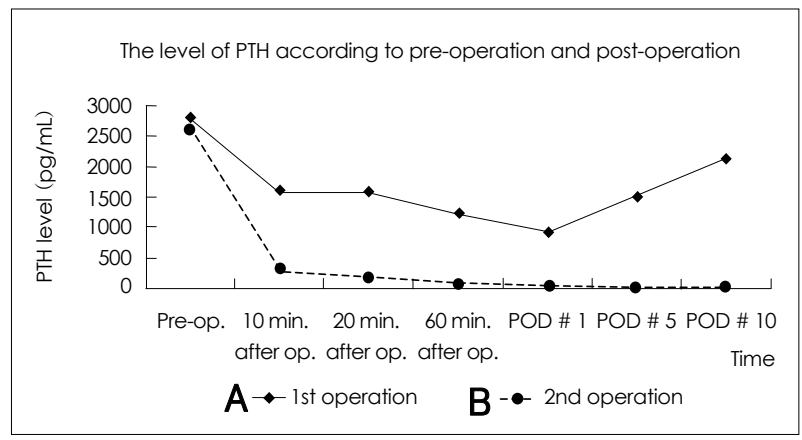

Fig. 3. The graph shows the shift of PTH level each preoperation, 10 minute later, 20 minute later, 60 minute later, 5 days and 10 days later. $1^{\text {st }}$ operation (A), $2^{\text {nd }}$ operation (B). PTH: parathyroid hormone.
Fig. 2. Pre-operative Neck CT finding shows several well enhancing nodules seen behind thyroid glands (arrow).
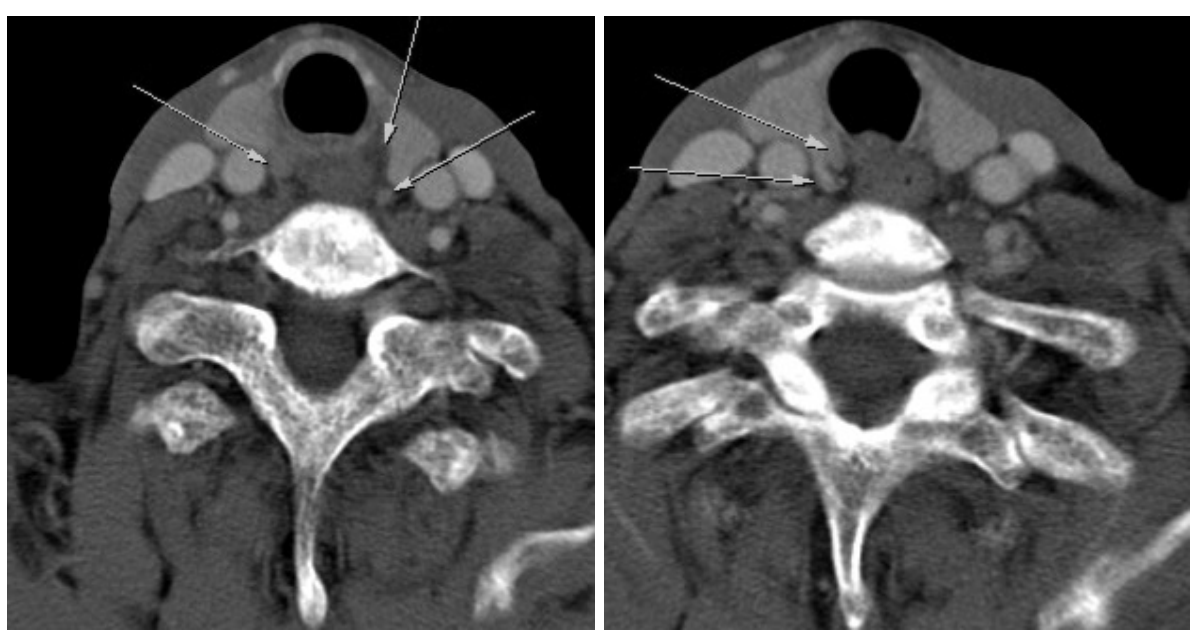
Fig. 4. $1^{\text {st }}$ operative finding shows the supernumerary parathyroid $\mathrm{gl}$ and located on left central neck region (arrow)(A), SPECT-CT finding after $1^{\text {st }}$ parathyroidectomy presents abnormal parathyroid tissue on medial aspect of right subclavian artery (arrow)(B).
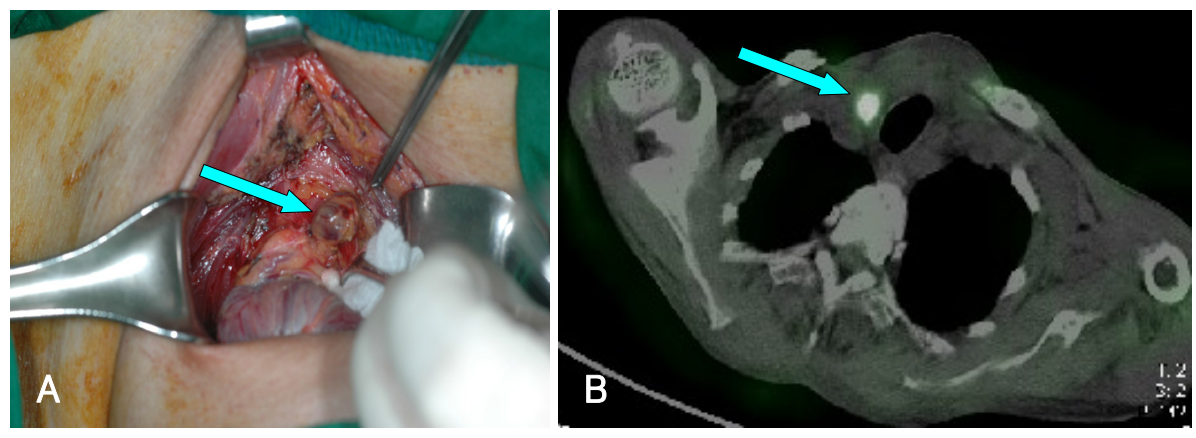

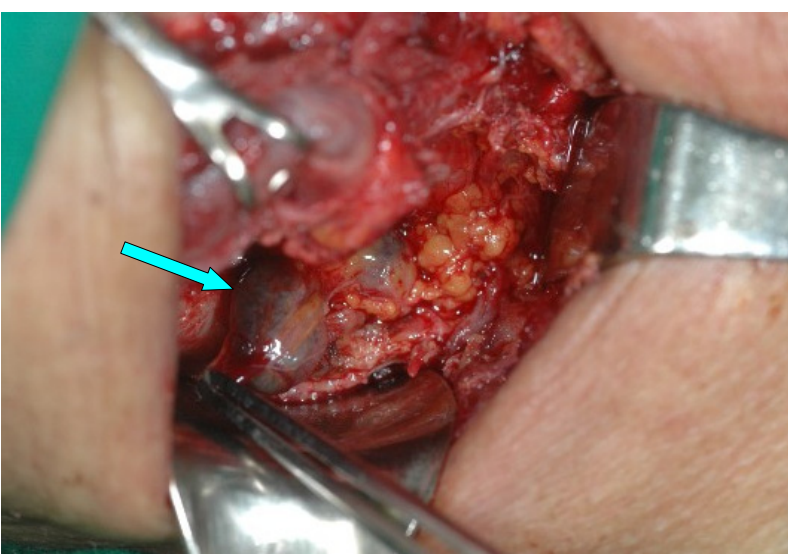

Fig. 5. $2^{\text {nd }}$ operative finding shows the supernumerary parathyroid gland located on right retroesophageal space (arrow).

제거 직전, 10 분, 20 분, 60 분 후의 $\mathrm{iPTH}$ 는 $2,624.0 \mathrm{pg} / \mathrm{mL}$, $236.4 \mathrm{pg} / \mathrm{mL}, 177.4 \mathrm{pg} / \mathrm{mL}, 53.6 \mathrm{pg} / \mathrm{mL}$ 로 급격한 감소 소견을 보여 수술을 종료하였다(Fig. 3). 환자는 술 후 관리 를 위해 신장 내과로 전과 되어 집중 치료를 받은 후, 특별한 합병증 없이 퇴원하였고, 현재 외래에서 2 개월간 추적관찰 중이다. 술 후 최종조직검사 소견상 모두 부갑상선 증식증 으로 확인되었고, 그 외에 2 개의 흉선 조직도 발견되었다.

\section{고 찰}

이차성 부갑상선 기능항진증은 신기능의 감소에 의해 비 타민 D 대사의 장애에 따른 위장관 내에서의 칼슘 흡수 장 애, 고인산혈증에 의해 상대적으로 과잉 생산된 부갑상선 호 르몬으로 인해 골조직을 비롯한 체내 조직에서 칼슘이 배 출되어 골성 통증과 고칼슘혈증이 나타나 전신증상을 유발 하게 된다. Uno 등 ${ }^{3}$ 은 만성 신부전에 의한 이차성 부갑상 선 기능항진증의 경우 부갑상선이 이소성으로 종종 흉선 조직에 위치함을 보고하고, 이차성 부갑상선 기능항진증 환자의 수술에 있어 선택적 흉선절제술 또한 충분히 고려 되어져야 한다고 주장하였다. 실제 본 증례의 환자에서도 선택적으로 흉선을 제거하였다. 만성 신부전에 의한 이차
성 부갑상선 기능항진증 환자에서 수술의 임상적 적응증은 1990년 미국 국립보건원에서 제시한 적응증을 기준으로 하여 증세가 있거나, 나이가 50세 이하이거나, 심한 고칼 슘혈증이 있거나(정상보다 $1 \sim 1.6 \mathrm{mg} / \mathrm{dL}$ 이상), 소변 내 칼슘치가 $400 \mathrm{mg} / 24 \mathrm{hr}$ 이상인 경우, 연령을 보정한 골량 이 표준편차 2 배 이하인 경우이다. ${ }^{4)}$ 본 증례의 환자도 내 원 당시 골 통증 및 높은 혈중 부갑상선 호르몬 농도를 토 대로 수술적 치료를 결정하였다. 부갑상선 기능항진증에 대 한 수술은 술 후에도 지속적인 부갑상선 기능항진증이 5 $10 \%$ 에서 나타날 정도로 경험이 많은 술자에 의해서도 적 지 않은 실패율을 보인다.,6) 한편, 부갑상선 절제수술 후 재 발의 원인으로는 부갑상선 과증식증을 단일 선종으로 잘못 진단한 경우와 초과수 부갑상선, 이소성 부갑상선, 부갑상 선 아전절제술 후 잔존 부갑상선의 증식 등을 들 수 있다. ${ }^{7)}$ 초과수 부갑상선의 존재로 인한 수술 실패는 수술 중의 부 갑상선 호르몬 측정으로 어느 정도 극복할 수 있다. 이는 부 갑상선 호르몬의 반감기가 $3 \sim 5$ 분 정도로 짧은 것을 이용 하여 부갑상선 절제 전후의 부갑상선 호르몬 수치를 비교함 으로써 $50 \%$ 이상 감소되는 경우 잔존 부갑상선 조직이 없 을 것으로 예상할 수 있다. 부갑상선 호르몬 수치가 정상범 위로 돌아오는 여부보다는 $50 \%$ 의 감소가 더 중요한 지표 가 되며, $50 \%$ 미만으로 감소되는 경우에는 잔존 부갑상선 조직의 유무를 계속 확인해야 한다. ${ }^{8)}$ 이 방법은 $95 \%$ 정도 의 정확도를 보여 불필요한 조직 손상과 계류 부갑상선을 피할 수 있는 장점이 있다. ${ }^{8)}$ 숙련된 외과의에 의해 갑상선 수술이 시행될 때에도, 약 $9 \%$ 정도에서 우발적인 부갑상선 절제술이 시행된다고 한다. ${ }^{9)}$ 이차성 부갑상선 기능항진증 에서 부갑상선의 국소화를 위해 methylene blue를 사용하 여 성공한 사례가 보고되었다. 수술 중에 절제한 부갑상선 중에 90.1\%(82/91)가 주변조직과 구별되었으며, 수술 중 에 유용한 국소화 방법으로 보고하였다. ${ }^{10)}$ 부갑상선이 선택 적으로 methylene blue에 염색되는 기전은 잘 알려져 있 지 않다. 적출한 부갑상선 선종에서 조직학적으로 주세포 (chief cell) 보다는 미토콘드리아(mitochondria) 가 풍부한 
호산성 세포(oxyphil cell) 에 주로 염색되었음이 보고되었 고, 부갑상선 선종에서 호산성 세포가 증가되어 있으며, Tc$99 \mathrm{~m} \mathrm{MIBI}$ 가 미토콘드리아에 선택적으로 축적될 가능성에 대해 제시하였다. ${ }^{11)}$ 수술의 알고리즘은 우선 술 전에 부갑상 선 국소화검사에서 과증식된 부갑상선을 찾은 후 methylene blue에 염색된 양측의 상, 하 부갑상선을 확인하여 제 거한 후 동결절편검사로 확인하였다. 이후 초과수 부갑상 선의 존재 여부를 고려하여 술 중 부갑상선호르몬을 10 분, 20 분, 60 분 간격으로 측정하여 효과적으로 부갑상선이 제 거되었는지 확인하였다. 이후 정상 부갑상선의 확장 부위인 흥선, 상부 종격동을 탐색하는 방법을 선택하였다.

결론적으로 2 차성 부갑상선 기능항진증 환자에서 수술 은 훌륭한 치료법이며, 술자는 외과적 절제에 있어 초과수 부갑상선의 가능성을 염두에 두고, 술 중 부갑상선 호르몬 농도의 측정 및 methylene blue 시약을 통해 부갑상선의 정확한 확인 및 제거가 이루어져야 함을 본 증례를 통해서 알 수 있다.

\section{REFERENCES}

1) Gough I. Reoperative parathyroid surgery: the importance of ectopic location and multigland disease. ANZ J Surg 2006;76(12):1048-50.

2) Gauger PG, Doherty GM. Sabiston Textbook of Surgery: The Biological Basis of Modern Surgical Practice. 17 ed. Philadelphia: Elsevier Saunders;2004.

3) Uno N, Tominaga Y, Matsuoka S, Tsuzuki T, Shimabukuro S, Sato T, et al. Incidence of parathyroid glands located in thymus in patients with renal hyperparathyroidism. World J Surg 2008;32 (11):2516-9.

4) Krempl GA, Medina JE. Current issues in hyperparathyroidism. Otolaryngol Clin North Am 2003;36 (1):207-15.

5) Kaplan EL, Yashiro T, Salti G. Primary hyperparathyroidism in the $1990 \mathrm{~s}$. Choice of surgical procedures for this disease. Ann Surg 1992;215 (4): 300-17.

6) Simeone DM, Sandelin K, Thompson NW. Undescended superior parathyroid gland: a potential cause of failed cervical exploration for hyperparathyroidism. Surgery 1995;118(6):949-56.

7) Levin KE, Clark $\mathrm{OH}$. The reasons for failure in parathyroid operations. Arch Surg 1989;124 (8) :911-4; discussion 914-5.

8) Proctor MD, Sofferman RA. Intraoperative parathyroid hormone testing: what have we learned? Laryngoscope 2003;113 (4) :706-14.

9) Lin DT, Patel SG, Shaha AR, Singh B, Shah JP. Incidence of inadvertent parathyroid removal during thyroidectomy. Laryngoscope 2002;112(4):608-11.

10) Bland KI, Tidwell S, von Fraunhofer JA, Morris RR, McCoy MT, Wathen RL. Intraoperative localization of parathyroid glands using methylthionine chloride/tetramethylthionine chloride in secondary hyperparathyroidism. Surg Gynecol Obstet 1985;160 (1):42-8.

11) Lavelle MA, Glover FN. Hypercalcaemia. Parathyroidectomy. Br J Hosp Med 1984;31 (3) :204-8. 